\title{
Article \\ Cytotoxicity, Anti-Obesity and Anti-Diabetic Activities of Heteromorpha arborescens (Spreng.) Cham Leaves
}

\author{
Taiwo Oluwafunmilola Abifarin, Gloria Aderonke Otunola * $\mathbb{D}$ and Anthony Jide Afolayan
}

check for updates

Citation: Abifarin, T.O.; Otunola, G.A.; Afolayan, A.J. Cytotoxicity, Anti-Obesity and Anti-Diabetic Activities of Heteromorpha arborescens (Spreng.) Cham Leaves. Processes 2021, 9, 1671. https://doi.org/ $10.3390 /$ pr9091671

Academic Editor: Irena Žižović

Received: 9 August 2021

Accepted: 14 September 2021

Published: 16 September 2021

Publisher's Note: MDPI stays neutral with regard to jurisdictional claims in published maps and institutional affiliations.

Copyright: (c) 2021 by the authors. Licensee MDPI, Basel, Switzerland. This article is an open access article distributed under the terms and conditions of the Creative Commons Attribution (CC BY) license (https:// creativecommons.org/licenses/by/ $4.0 /)$.
Medicinal Plants and Economic Development (MPED) Research Centre, Department of Botany, University of Fort Hare, Alice 5700, South Africa; 201716181@ufh.ac.za (T.O.A.); aafolayan@ufh.ac.za (A.J.A.)

* Correspondence: gotunola@ufh.ac.za

\begin{abstract}
This study investigated the cytotoxicity, anti-obesity and anti-diabetic potentials of blanched, aqueous and ethanol extracts of Heteromorpha arborescens (Spreng.) Cham leaves. The results revealed that both ethanol and aqueous extracts exhibited considerable inhibition against $\alpha$-glucosidase $\left(\mathrm{IC}_{50}\right.$ of $627.29 \pm 4.62 \mu \mathrm{g} / \mathrm{mL}$ and $576.46 \pm 3.21 \mu \mathrm{g} / \mathrm{mL}$ respectively), while the blanched extract showed weak $\alpha$-glucosidase inhibition $\left(\mathrm{IC}_{50} ; 855.38 \pm 4.29 \mu \mathrm{g} / \mathrm{mL}\right.$ ) and the aqueous extract showed the best $\alpha$-amylase inhibition $\left(\mathrm{IC}_{50} ; 583.74 \pm 5.87 \mu \mathrm{g} / \mathrm{mL}\right.$ ). However, weak $\alpha$-amylase inhibition was observed in the ethanol $\left(\mathrm{IC}_{50} ; 724.60 \pm 4.33 \mu \mathrm{g} / \mathrm{mL}\right.$ ) and blanched extracts $\left(\mathrm{IC}_{50}\right.$; $791.63 \pm 3.76 \mu \mathrm{g} / \mathrm{mL}$ ). The toxicity of the extracts is indicated by $\mathrm{LC}_{50}$ values as $154.75 \mu \mathrm{g} / \mathrm{mL}$, $125 \mu \mathrm{g} / \mathrm{mL}$ and $90.58 \mu \mathrm{g} / \mathrm{mL}$ for ethanol, aqueous and blanched extracts respectively, indicating the blanched extract to be the most toxic. Moderate glucose utilization in both C3A and L6 cells was also observed for the aqueous and ethanol extracts which may be attributed to the relatively lower toxicity levels present. However, glucose utilization was very weak for the blanched extract, which may be due to higher level of cytotoxicity it possessed. Relatively weaker lipase inhibition was observed for the ethanol $\left(\mathrm{IC}_{50} ; 699.3 \pm 1.33 \mu \mathrm{g} / \mathrm{mL}\right)$, aqueous $\left(\mathrm{IC}_{50} ; 811.52 \pm 3.52 \mu \mathrm{g} / \mathrm{mL}\right)$ and blanched extracts $\left(\mathrm{IC}_{50} ; 1152.7 \pm 4.61 \mu \mathrm{g} / \mathrm{mL}\right.$ ) compared to orlistat $\left(\mathrm{IC}_{50} ; 56.88 \pm 0.11 \mu \mathrm{g} / \mathrm{mL}\right)$. However, there was no reasonable reduction in lipid accumulation observed in all the extract treated cells. These observations suggest that ethanol and aqueous extracts of $H$. arborescens leaf are promising as new agents for the treatment of diabetes and its acclaimed anti-obesity potentials are likely due to its lipase, $\alpha$-amylase and $\alpha$-glucosidase inhibition.
\end{abstract}

Keywords: diabetes mellitus; $\alpha$-glucosidase; $\alpha$-amylase; lipase; Heteromorpha arborescens; cytotoxicity; glucose utilization

\section{Introduction}

Diabetes mellitus is a chronic condition of carbohydrate, fat and protein metabolism impairment, characterized by hyperglycemia and glucose intolerance which is associated with insulin deficiency and/or insulin inefficiency [1,2]. This disease is a primary factor for global mortality, and it is well associated with long term complications such as cardiovascular diseases, retinopathy, neuropathy and oxidative stress [3,4]. $\alpha$-amylase and $\alpha$-glucosidase are carbohydrate digestive enzymes which catalyze the degradation of large insoluble starch molecules into digestible oligosaccharide molecules and the final breakdown of the oligosaccharides, respectively. One of the therapeutic approaches for reducing postprandial hyperglycemia is the inhibition of these enzymes to slow down absorption of carbohydrates in the small intestine [5-9]. Diabetes mellitus is also linked to obesity [10] and pancreatic lipase inhibitory activities as well as lipid accumulation have been widely used to determine the potential efficacy of natural products as anti-obesity agents [11]. Even though there is presently no cure for diabetes, there are several groups of artificial drugs which are commonly used for the management of diabetes: including sulfonylureas, thiazolidinediones, non-sulfonylurea insulin secretagogues, biguanides and 
$\alpha$-glucosidase inhibitors [12]. However, the use of these drugs is limited in that they are expensive; inaccessible for majority of the rural populations and some may have some undesirable aftermath such as excessive weight, diarrhea, nausea and gastrointestinal disorders [12-14]. On the other hand, medicinal plants are readily more available, with lower side effects compared to the conventional drugs and are a safer alternative for the management of diabetes and obesity $[15,16]$. Previous reports have indicated that some plant extracts possess bioactivity; however, the potency of these extracts may be altered by the cytotoxicity of the plants [17]. Hence the need to ascertain the safety and potency of plants before use.

A frequently used plant for the management of diabetes mellitus in South Africa is Heteromorpha arborescens [18-20]. This plant is highly reputed in the South African traditional medicine for the treatment of a wide range of diseases such as rheumatism, cancer, gonorrhea, heart problems, rabies and diabetes [21]. Several biological activities have also been reported for $H$. arborescens such as anticancer and antimalarial [22-25], antibacterial [26], aphrodisiac, antiulcer, anthelminthic, antinociceptive and analgesic [27] and anti-rabies activities [21]. Presumably, only very limited scientific information is available on the efficiency and safety of $H$. arborescens leaves in the treatment of diabetes and its related complications. Therefore, to validate this claim, the cytotoxic, inhibitory activities against $\alpha$-amylase, $\alpha$-glucosidase and lipase in addition to lipid accumulation potentials of the aqueous, blanched and ethanol extracts of $H$. arborescens leaves were determined.

\section{Materials and Methods}

\subsection{Chemicals, Reagents, Cell Lines}

Melphalan, Dimethyl Sulfoxide (DMSO), Hoechst 33342, Propidium iodide (PI), p-nitrophenol palmitate (pNPP), dinitrosalicylic acid (DNSA), Triton X-100, Tris- $\mathrm{HCl}$ buffer, monosodium and disodium phosphate, acarbose, -nitrophenyl-d-glucopyranoside p-nitrophenyl- $\alpha$-D-glucopyranoside (pNPG), sodium carbonate, $\alpha$-glucosidase, $\alpha$-amylase, isopropanol, Triton X-100, Metformin, Dulbecco's Modified Eagle Medium (DMEM) and Tris- $\mathrm{HCl}$ buffer were purchased from Sigma-Aldrich through Capital Lab Supplies, South Africa. Bovine Serum Albumin (BSA), starch and insulin were purchased from Sigma (St. Louis, MO, USA). Fetal Calf Serum (FCS), Roswell Park Memorial Institute (RPMI) 1640 Medium and 3-(4, 5-Dimethylthiazol-2-yl)-2, 5-diphenyltetrazolium bromide (MTT) were purchased from GE Healthcare Life Sciences (Logan, UT, USA). The C3A/HepG2 cells and L6 cell lines were obtained from Professor Maryna van de Venter, of the Department of Biochemistry and Microbiology, Nelson Mandela University (NMU), South Africa, where the assays were performed.

\subsection{Plant Collection}

Fresh $H$. arborescens leaves were collected from Alice, Eastern Cape, South Africa $\left(32^{\circ} 47^{\prime} 50.4^{\prime \prime} \mathrm{S}, 26^{\circ} 52^{\prime} 41.8^{\prime \prime}\right.$ E). The plant was validated by Prof. Cupido, a Taxonomist, and a voucher specimen (Abif2019/03) was stored in the Giffen Herbarium, University of Fort Hare.

\subsection{Preparation of Extracts}

Oven dried powdered $H$. arborescens leaves $(100 \mathrm{~g})$ were extracted separately in $500 \mathrm{~mL}$ of ethanol and water for $24 \mathrm{~h}$ on an orbital shaker. For the blanched sample, the same weight of the fresh leaves was extracted in $500 \mathrm{~mL}$ of hot water $\left(80^{\circ} \mathrm{C}\right)$ for $5 \mathrm{~min}$ to simulate home cooking, and then ground with a blender. All the extracts were filtered using a Buchner funnel and Whatman filter paper $(150 \mathrm{~mm})$ under a vacuum. The ethanol extract was concentrated to dryness using a rotary evaporator while the aqueous extract and blanched samples were subjected to freeze drying. 


\subsection{Maintenance of Cell Culture}

The cell cultures were incubated in a moistened environment with $5 \% \mathrm{CO}_{2}$ at $37^{\circ} \mathrm{C}$. Growth medium (RPMI 1640 medium plus 10\% fetal calf serum) was supplied to the C3A cells once in 3 days, and the L6 myoblast cells were cultivated in media containing the growth medium with no antibiotic. The cell lines were sub-cultured after $80 \%$ confluence.

\subsection{Cytotoxicity Assay}

Cytotoxicity of the extracts was determined using Hoechst/PI staining technique. The C3A cells were seeded in 96-well plates at a density of 6000 cells per well in DMEM containing $10 \%$ Fetal Bovine serum and allowed to attach overnight. The cells were thereafter treated by replacing the medium with fresh ones at different extract concentrations $(12.5-200 \mu \mathrm{g} / \mathrm{mL})$ and the treated cells were incubated for $48 \mathrm{~h}$. After incubation, the spent media were carefully removed and $50 \mu \mathrm{L}$ staining solution (5 mL PBS containing $2 \mu \mathrm{L}$ Hoechst solution $(10 \mathrm{mg} / \mathrm{mL}$ in DMSO) was added to each well. The samples were incubated again at $37^{\circ} \mathrm{C}$ for $15 \mathrm{~min}$. Thereafter, $50 \mu \mathrm{L}$ PI staining solution was added to each well at a concentration of $2 \mu \mathrm{g} / \mathrm{mL}$ and image was acquired using DAPI $\left(4^{\prime}, 6-\right.$ diamidino-2-phenylindole) and Texas Red filters. Melphalan, a well-known cytotoxic drug was used as the positive control. Cytotoxic activity was calculated as:

$$
\% \text { Cell density }=\frac{\mathrm{A} 570 \mathrm{~nm} \text { of treated cells }}{\mathrm{A} 570 \mathrm{~nm} \text { of untreated cells }} \times 100
$$

\subsection{Alpha-Amylase Inhibition}

The $\alpha$-amylase inhibition assay was performed using the 3,5-dinitrosalicylic acid (DNSA) method. The plant extract was dissolved in very little quantity of $10 \%$ DMSO and was further diluted with buffer solution $(\mathrm{pH}$ 6.9) in a 96-wells microtiter plate, to obtain varying concentrations between $50-200 \mu \mathrm{g} / \mathrm{mL}$. $5 \mu \mathrm{L}$ of $\alpha$-amylase solution was added separately to $15 \mu \mathrm{L}$ of the extracts, phosphate buffer (negative control) and acarbose, after which the mixture was pre-incubated for $30 \mathrm{~min}$ at $37^{\circ} \mathrm{C}$. The reaction was initiated by adding $20 \mu \mathrm{L}$ of the starch solution to each well and the resulting mixture incubated for another $30 \mathrm{~min}$ at $37^{\circ} \mathrm{C}$. The reaction was thereafter terminated by the addition of $20 \mu \mathrm{L}$ DNSA reagent and was heated for $10 \mathrm{~min}$ in a water bath at $90^{\circ} \mathrm{C}$. The mixture was cooled to room temperature and the absorbance was measured at $540 \mathrm{~nm}$. The $\alpha$-amylase inhibitory activity expressed as percentage inhibition was calculated as:

$$
\% \text { Inhibition }=\frac{\mathrm{Abs}_{\text {control }}-\mathrm{Abs}_{\text {Sample }}}{\mathrm{Abs}_{\text {control }}} \times 100
$$

\subsection{Alpha-Glucosidase Inhibition}

The $\alpha$-glucosidase inhibition assay was determined as described [28]. Briefly, $5 \mu \mathrm{L}$ of the extracts (30 60, 120, 240 and $480 \mu \mathrm{g} / \mathrm{mL}$ ), $20 \mu \mathrm{L}$ of $50 \mu \mathrm{g} / \mathrm{mL} \alpha$-glucosidase solution and $60 \mu \mathrm{L}$ of $67 \mathrm{mM}$ potassium phosphate buffer ( $\mathrm{pH}$ 6.8) were reacted together in a 96-well plate. After $5 \mathrm{~min}$ of incubation, $10 \mu \mathrm{L}$ of $10 \mathrm{mM}$ p-nitro phenyl- $\alpha$-D-glucoside solution (PNPGLUC) was added and then further incubated at $37^{\circ} \mathrm{C}$ for $20 \mathrm{~min}$. Thereafter, $25 \mu \mathrm{L}$ of $100 \mathrm{mM} \mathrm{Na}_{2} \mathrm{CO}_{3}$ solution was added to the mixture and the absorbance was measured at $405 \mathrm{~nm}$. Acarbose $(10 \mu \mathrm{g} / \mathrm{mL})$ was prepared in separate wells and used as the positive control. The \% inhibition was calculated as:

$$
\% \text { Inhibition }=\frac{\mathrm{Abs}_{\mathrm{control}}-\mathrm{Abs}_{\text {Sample }}}{\mathrm{Abs} \text { control }} \times 100
$$

\subsection{Pancreatic Lipase Inhibition}

In vitro pancreatic lipase inhibitory assay was performed as described $[29,30]$ with some modifications. Briefly, $20 \mu \mathrm{L}$ of extracts and orlistat $(1 \mathrm{mg} / \mathrm{mL}$ stock solution in $10 \%$ DMSO) at varying concentrations $(30,60,120,240$ and $480 \mu \mathrm{g} / \mathrm{mL})$ was reacted with $100 \mu \mathrm{L}$ 
of freshly prepared lipase enzyme solution $(1 \mathrm{mg} / \mathrm{mL})$. The resulting mixtures were made up to $1 \mathrm{~mL}$ by adding Tri- $\mathrm{HCl}$ solution ( $\mathrm{pH} 7.4)$ and then incubated at $25^{\circ} \mathrm{C}$ for $15 \mathrm{~min}$. After incubation, $100 \mu \mathrm{L}$ of the substrate solution (20.9 $\mathrm{mg}$ of PNPB in $2 \mathrm{~mL}$ of acetonitrile) was added. The mixture was incubated again for $30 \mathrm{~min}$ at $37^{\circ} \mathrm{C}$ and the absorbance was measured at $405 \mathrm{~nm}$. Orlistat was used as the positive control and controls without orlistat and without the substrate (PNPB) were separately prepared. The percentage inhibition was calculated as:

$$
\% \text { Inhibition }=\frac{\mathrm{Abs}_{\text {control }}-\mathrm{Abs}_{\text {Sample }}}{\mathrm{Abs}_{\text {control }}} \times 100
$$

\subsection{Lipid Accumulation Assay}

Lipid accumulation in C3A cells was determined as previously described by [31]. The C3A cells were seeded in 96-well plates at a density of 6000 cells per well in DMEM containing 10\% Fetal Bovine serum and allowed to attach overnight. The cells were afterwards treated with different extract concentrations $(12.5,25,50,100$ and $200 \mu \mathrm{g} / \mathrm{mL})$ or positive control (Chloroquine) and 1000X LipidTox Green phospholipidosis detection reagent (diluted 1:500 in $5 \mathrm{~mL}$ complete growth medium), filtered using a $0.2 \mu \mathrm{m}$ syringe filter before addition to wells, containing treatment. The treated cells were thereafter incubated for two days. The spent media was removed, washed with $200 \mu \mathrm{L}$ PBS per well and fixed overnight in $4 \%$ formaldehyde. Fifty microliters of staining solution (prepared as $10 \mathrm{~mL}$ of PBS plus $10 \mu \mathrm{L}$ LipidTox Red and $2 \mu \mathrm{L}$ Hoechst) was added to each well and the mixture was incubated at room temperature for 30min. Image acquisition was then done using DAPI and Texas Red filters.

\subsection{Glucose Utilization}

Glucose utilization on L6 myoblasts cells was determined as previously described [32], with slight modifications. The cells were grown in DMEM supplemented with 10\% FCS and sub-cultured by trypsinization. The L6 cells were further seeded into 96-well culture plates at a density of 5000 cells per well and allowed until $80 \%$ confluence of the medium was attained and at least one row was left empty without cells (blanks). The cells were incubated for 5 days to allow sufficient time for full differentiation and thereafter, the spent medium was removed from the differentiated cells and replaced with $200 \mu \mathrm{L}$ per well of fresh medium at varying concentrations $(12.5,25,50,100$ and $200 \mu \mathrm{g} / \mathrm{mL})$. A row of the wells was treated with insulin $(12 \mu \mathrm{M})$ which served as the positive control. Treatment was continued for two days and the cells were washed once with $50 \mu \mathrm{L}$ of incubation buffer solution containing RPMI medium diluted with PBS and supplemented with BSA and $8 \mathrm{mM}$ glucose to a final concentration of $0.1 \%$. The plates were thereafter incubated for $2 \mathrm{~h}$ at $37^{\circ} \mathrm{C}$. After incubation, $5 \mu \mathrm{L}$ of the culture medium was transferred to a new 96-well plate and to the wells; $200 \mu \mathrm{L}$ glucose assay reagent (glucose oxidase/peroxidase colorimetric reagent) was added and incubated a $37{ }^{\circ} \mathrm{C}$ for $10-20 \mathrm{~min}$ and absorbance was measured at $510 \mathrm{~nm}$. Glucose utilization was calculated as the difference between the wells with no cells and the wells containing cells and the amount of glucose utilized was expressed as a percentage of the untreated controls. Cell viability was then determined as $100 \mu \mathrm{L}$ MTT solution $(0.5 \mathrm{mg} / \mathrm{mL}$ in DMEM) was added to each well and further incubated at $37{ }^{\circ} \mathrm{C}$ for $1 \mathrm{~h}$. Thereafter, the MTT solution was removed, $200 \mu \mathrm{L}$ DMSO added, and the wells were again incubated at room temperature for $20 \mathrm{~min}$. Absorbance was then measured at $540 \mathrm{~nm}$ and the cytotoxicity expressed as a percentage of the untreated control.

\subsection{Data Analysis}

The experiments were performed in triplicates and data were expressed as mean \pm standard deviation (SD) values using one way analysis of variance (ANOVA) and Fischer's Least Significant Difference in MINITAB 17 statistical package. Values were regarded as significantly different when $p<0.05$. 


\section{Results}

\subsection{Cytotoxicity}

The cytotoxic effect of each sample and standard, as well as the well-known cytotoxic drug (melphalan), is presented in Figures 1 and 2. The effect of the extracts on C3A cells suggests increased toxicity with increased concentration. The three extracts showed a decline in cell density at higher concentrations with the aqueous and ethanol extracts indicating a very sharp drop in cell density at the maximum concentration tested $(200 \mu \mathrm{g} / \mathrm{mL})$ whereas, the blanched extracts showed a sharp decline in cell density from as low as $100 \mu \mathrm{g} / \mathrm{mL}$ and melphalan on the other hand showed normal dose dependent simultaneous increase in dead cells and at the maximum concentration $(200 \mu \mathrm{g} / \mathrm{mL})$, all the extracts exhibited more than $50 \%$ cell death. The Lethal Concentration $50\left(\mathrm{LC}_{50}\right)$ were $154.75 \mu \mathrm{g} / \mathrm{mL}, 125 \mu \mathrm{g} / \mathrm{mL}$ and $90.58 \mu \mathrm{g} / \mathrm{mL}$ for ethanol, aqueous and blanched extracts respectively, indicating the blanched extract to be the most toxic. The corresponding images of the cells obtained from Hoechst 33,342 staining are presented in Figure 3.

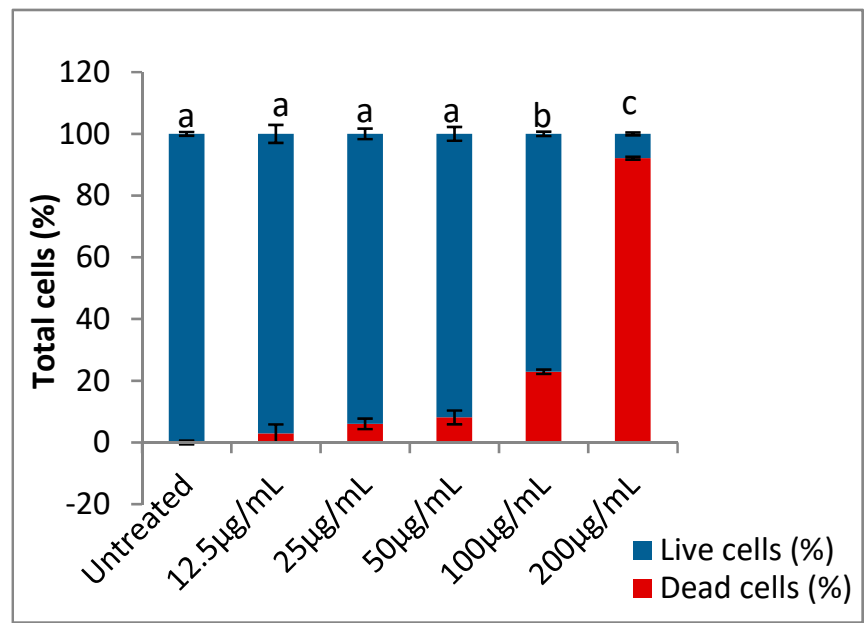

(a)

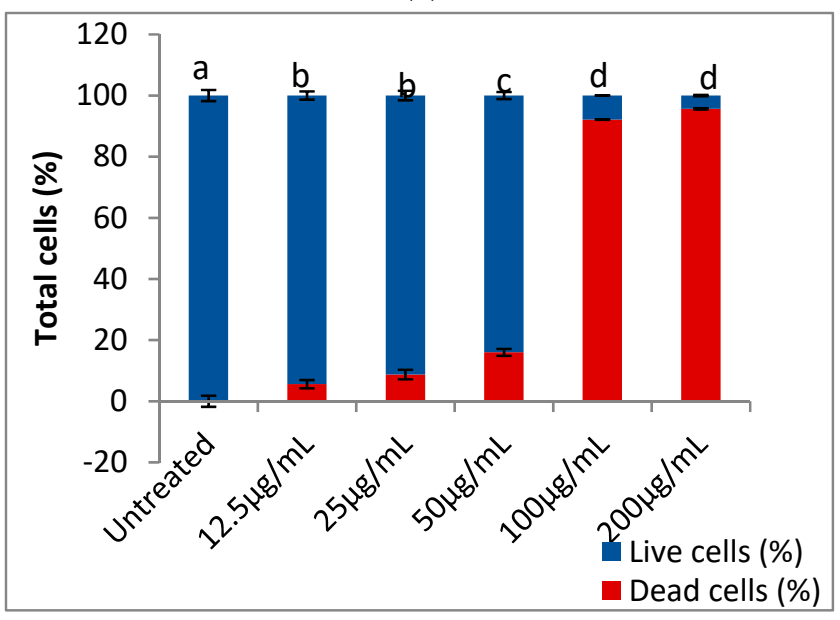

(c)

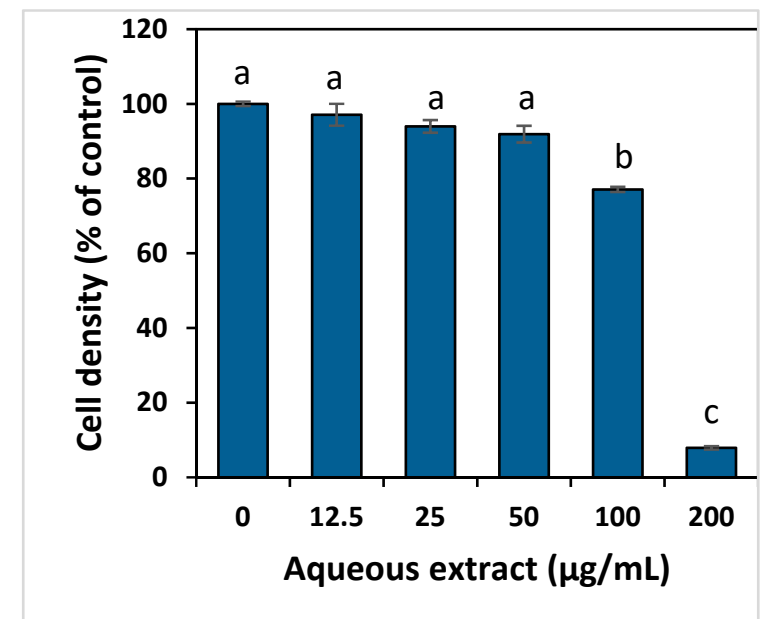

(b)

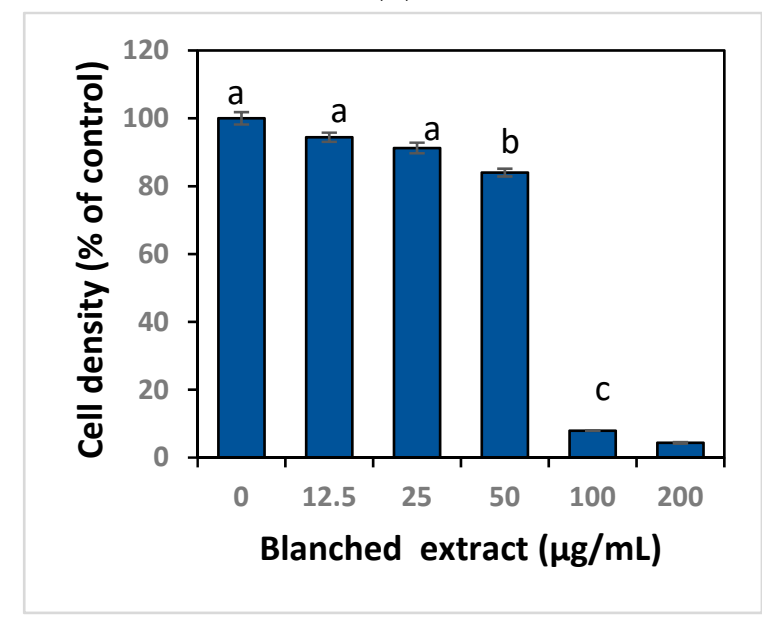

(d)

Figure 1. Cytotoxicity screening of aqueous and blanched extracts of H. arborescens leaves. (a) Total number of C3A cells after treatment with aqueous extract. (b) Cell density after treatment with aqueous extract. (c) Total number of C3A cells after treatment with blanched extract. (d) Cell density after treatment with blanched extract. Dead cells were represented as cells with compromised membrane integrity and subsequent propidium iodide (PI) staining and Live cells obtained from Hoechst 33,342 staining. Values are expressed as mean \pm SD $(n=2)$. Mean separation by SD $(p<0.05)$. Set of bars with different alphabets are significantly different. 


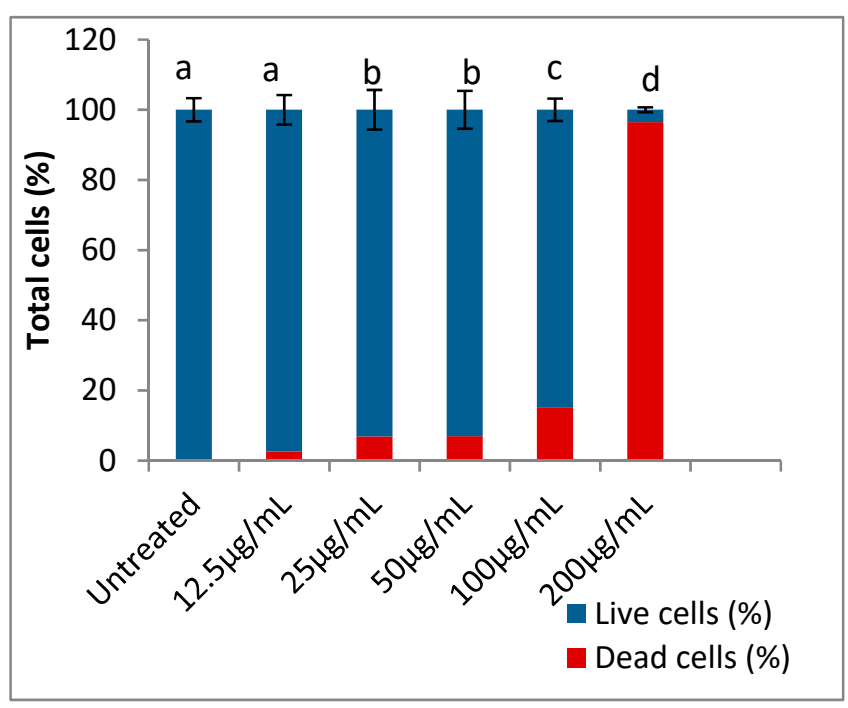

(a)

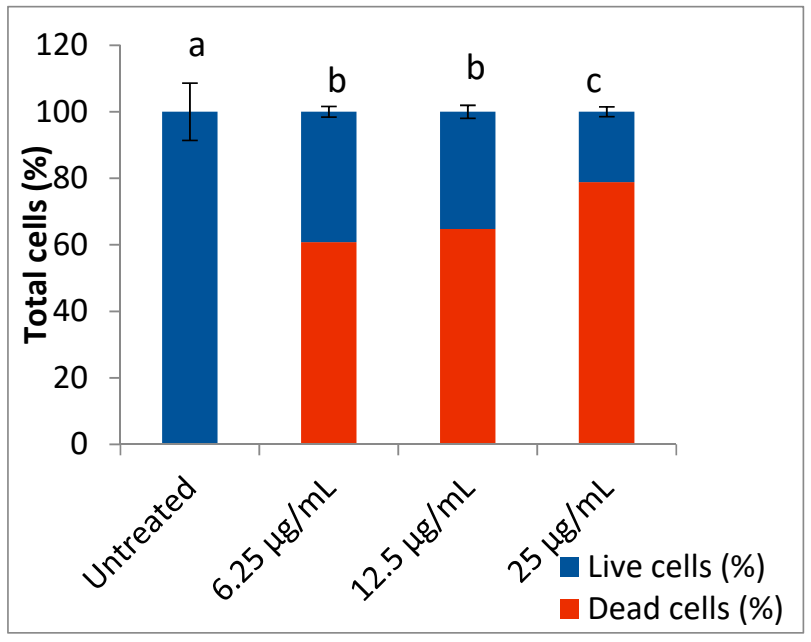

(c)

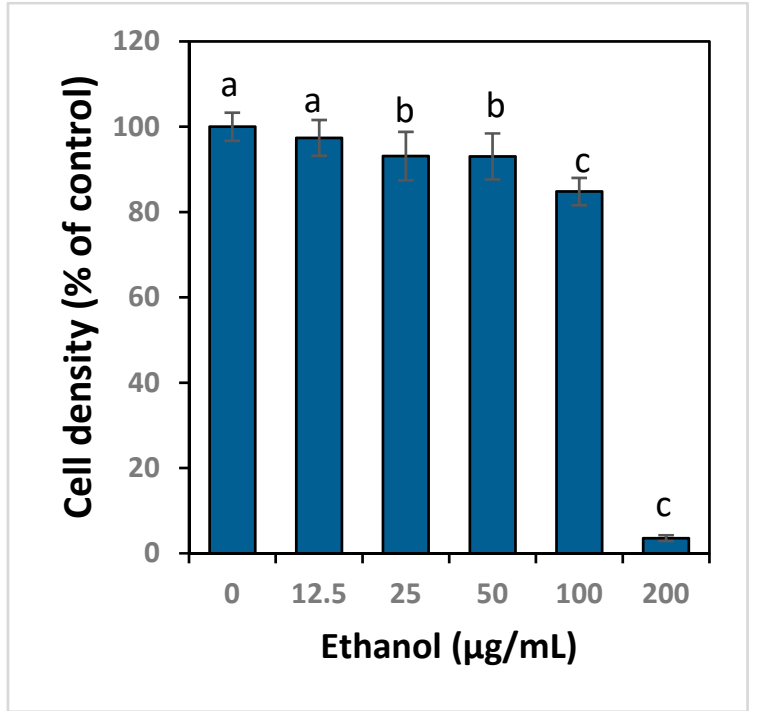

(b)

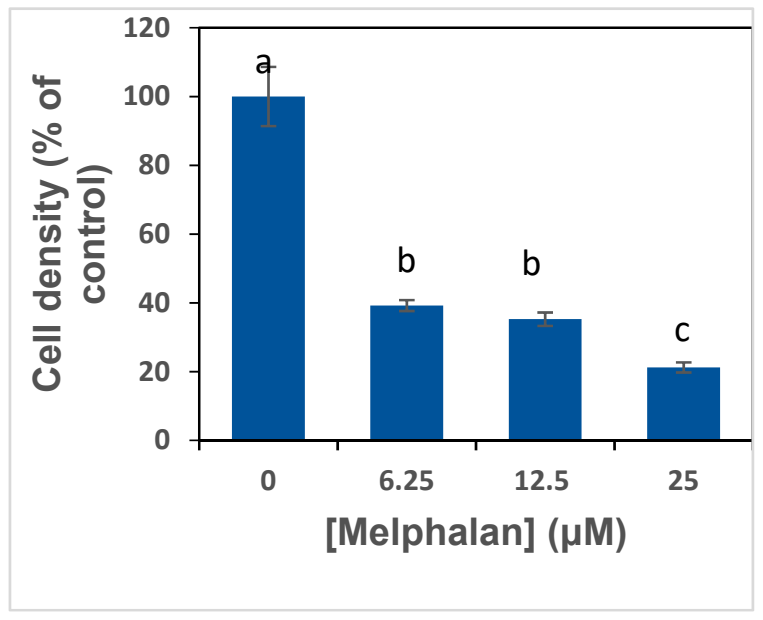

(d)

Figure 2. Cytotoxicity screening of ethanol extract of $H$. arborescens leaves and melphalan (positive control). (a). Total number of C3A cells after treatment with ethanol extract. (b) Cell density after treatment with ethanol extract. (c) Total number of C3A cells after treatment with Melphalan. (d) Cell density after treatment with Melphalan. Dead cells were represented as cells with compromised membrane integrity and subsequent propidium iodide (PI) staining and Live cells obtained from Hoechst 33,342 staining. Values are expressed as mean $\pm \operatorname{SD}(n=2)$. Mean separation by $\operatorname{SD}(p<0.05)$. Set of bars with different alphabets are significantly different. 
A
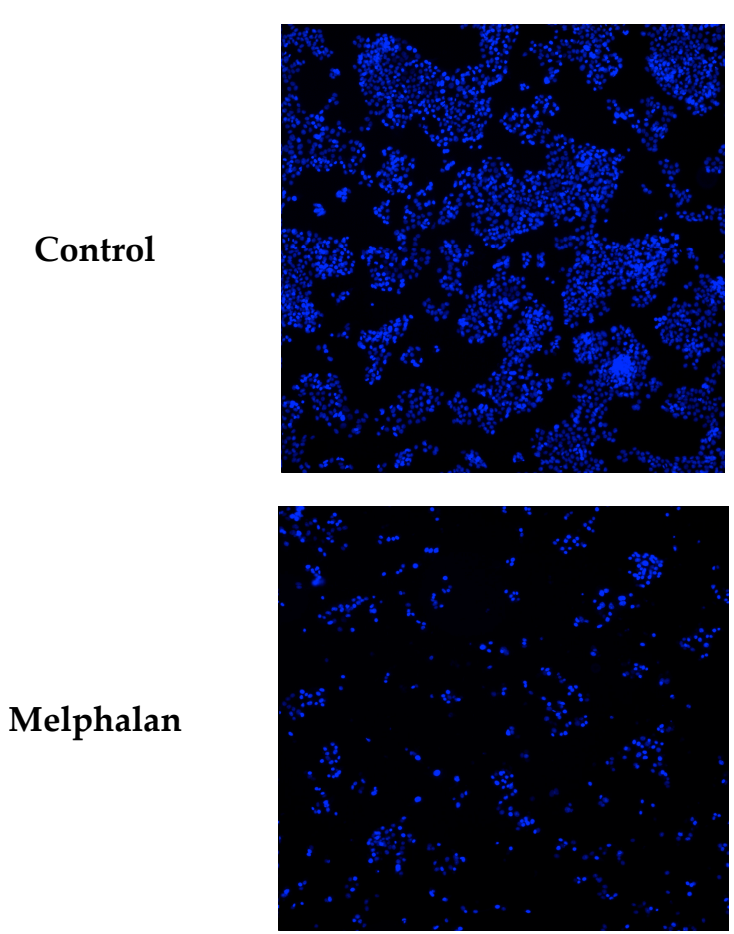

Ethanol

Blanched

Aqueous
B
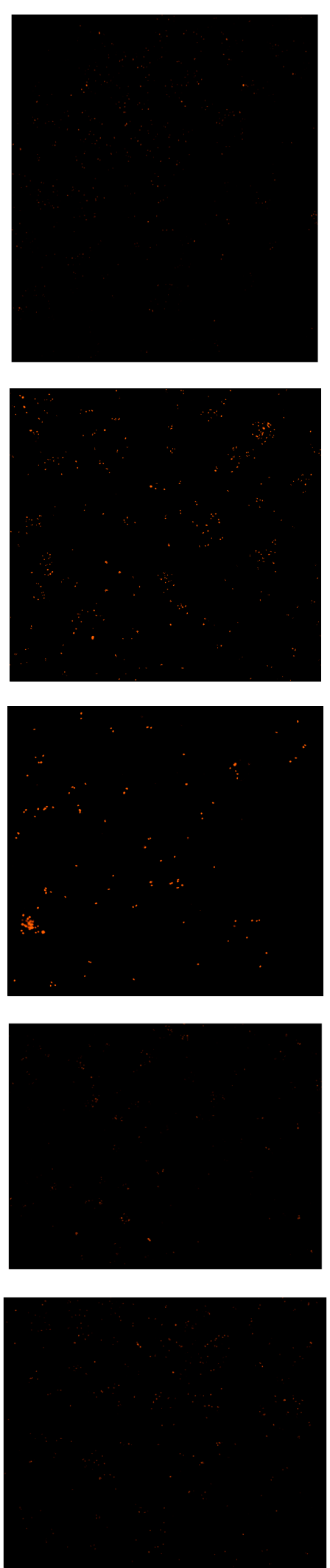

Figure 3. Images of C3A cells after $48 \mathrm{~h}$ treatment with $100 \mu \mathrm{g} / \mathrm{mL}$ each of ethanol, blanched and aqueous extracts of $H$. arborescens leaves obtained from Hoechst 33,342 staining. Column (A)—all nuclei, Column (B)—nuclei of dead cells. 


\subsection{Alpha-Amylase Inhibition}

The $\alpha$-amylase inhibition of $H$. arborescens leaf extracts and acarbose (positive control) is presented in Figure 4. The extracts displayed a concentration dependent inhibition of the enzyme, but very weak inhibitory potential at the tested concentrations when compared to acarbose. Percentage inhibition of $\alpha$-amylase enzyme ranged from $40.77 \pm 1.26 \%$ to $85.35 \pm 2.18 \%$ for acarbose, $2.32 \pm 0.45 \%$ to $32.46 \pm 0.49 \%$ for ethanol, $3.04 \pm 0.37 \%$ to $29.46 \pm 1.06 \%$ for blanched and $7.48 \pm 0.27 \%$ to $40.33 \pm 3.49 \%$ for the aqueous extract. The $\mathrm{IC}_{50}$ values (Table 1) were $51.06 \pm 1.78,583.74 \pm 5.87,724.66 \pm 4.33$ and $791.63 \pm 3.76 \mu \mathrm{g} / \mathrm{mL}$ for acarbose, aqueous, ethanol and blanched extracts respectively.

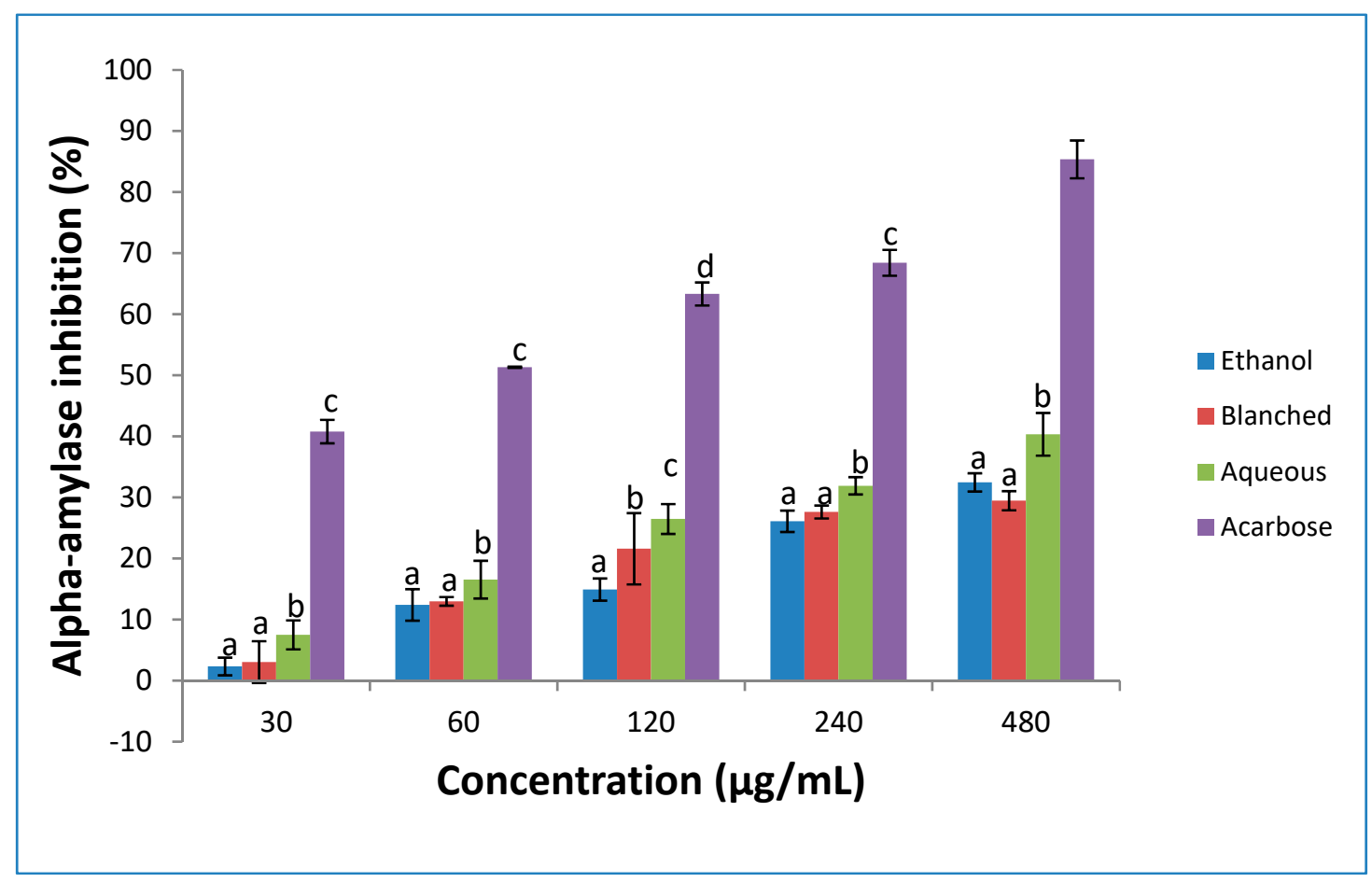

Figure 4. Alpha-amylase inhibitory activity of H. arborescens leaf extracts and positive control (acarbose). Values are mean $\pm \mathrm{SD}$ $(n=3)$. Mean separation by SD $(p<0.05)$. Set of bars (the same concentration) with different alphabets are different.

Table 1. $\mathrm{IC}_{50}$ values for $\alpha$-amylase and $\alpha$-glucosidase inhibition by $H$. arborescens leaf extracts and standards $(\mu \mathrm{g} / \mathrm{mL})$.

\begin{tabular}{cccc}
\hline Extracts & $\alpha$-Amylase & $\alpha$-Glucosidase & Lipase \\
\hline Ethanol & $724.66 \pm 4.33$ & $627.29 \pm 4.62$ & $699.3 \pm 1.33$ \\
\hline Blanched & $791.63 \pm 3.76$ & $855.38 \pm 4.29$ & $1152.7 \pm 4.61$ \\
\hline Aqueous & $583.74 \pm 5.87$ & $576.46 \pm 3.21$ & $811.52 \pm 3.52$ \\
\hline Acarbose & $51.06 \pm 1.78$ & $45.43 \pm 2.31$ & $*$ \\
\hline Orlistat & $*$ & $*$ & $56.88 \pm 0.11$ \\
\hline
\end{tabular}

* Not determined.

\subsection{Alpha-Glucosidase Inhibitory Assay}

The $\alpha$-glucosidase inhibitory potential of $H$. arborescens leaf extracts and acarbose (positive control) is indicated in Figure 5. The extracts showed considerable dose dependent $\alpha$-glucosidase inhibition, although weaker when compared to acarbose. Percentage inhibition of $\alpha$-glucosidase enzyme ranged from $44.11 \pm 0.19 \%$ to $82.47 \pm 3.26 \%$ for acarbose, $18.43 \pm 0.89 \%$ to $40.69 \pm 1.03 \%$ for ethanol extract, $9.32 \pm 0.06 \%$ to $31.72 \pm 1.13 \%$ for blanched extract and $22.63 \pm 1.38 \%$ to $43.97 \pm 0.38 \%$ for the aqueous extract. The $\mathrm{IC}_{50}$ 
values (Table 1) were $45.43 \pm 2.31,576.46 \pm 3.21,627.29 \pm 4.33$ and $855.38 \pm 4.29 \mu \mathrm{g} / \mathrm{mL}$ for acarbose, aqueous, ethanol and blanched extracts respectively.

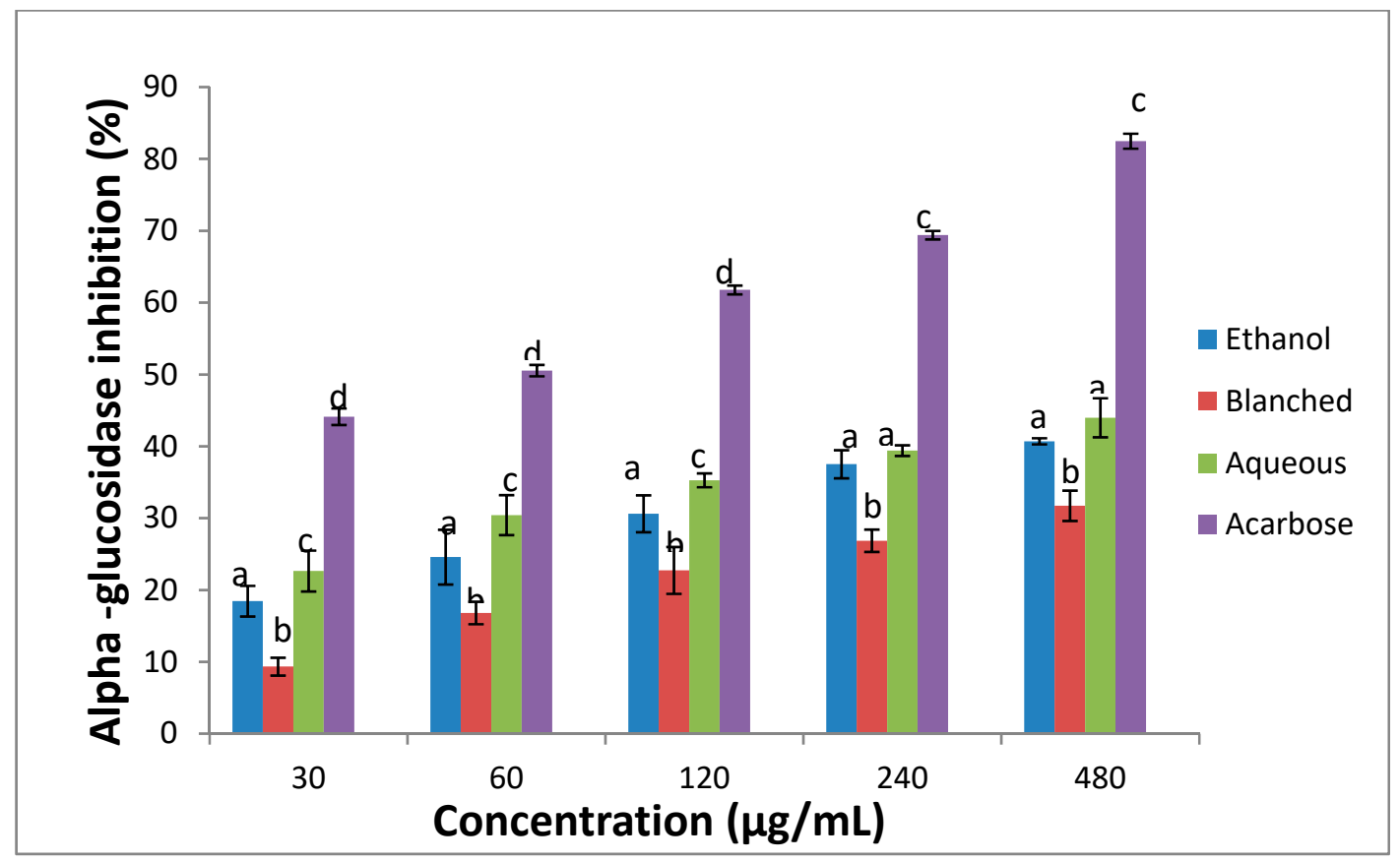

Figure 5. Alpha-glucosidase inhibitory activity of $H$. arborescens leaf extracts and positive control (acarbose). Values are expressed as mean $\pm \mathrm{SD}(n=3)$. Mean separation by SD $(p<0.05)$. Bars at the same concentration with different alphabets are significantly different.

\subsection{Porcine Pancreatic Lipase}

The inhibitory effects of the $H$. arborescens leaf extracts against porcine pancreatic lipase were evaluated in comparison with orlistat (Positive control) and presented in Figure 6. Although percentage inhibition ranged from $46.33 \pm 0.76 \%$ to $82.07 \pm 1.41 \%$ for orlistat, $12.30 \pm 0.85 \%$ to $35.87 \pm 1.39 \%$ for ethanol, $3.88 \pm 1.37 \%$ to $25.65 \pm 2.33 \%$ for blanched and $9.57 \pm 0.66 \%$ to $31.21 \pm 1.34 \%$ for aqueous extract. Among the extracts assessed, ethanol extract showed the most active lipase inhibitory activities with $\mathrm{IC}_{50}$ values of $699.3 \pm 1.33 \mu \mathrm{g} / \mathrm{mL}$, followed by aqueous extract $(811.52 \pm 3.52 \mu \mathrm{g} / \mathrm{mL})$ and blanched extract $(1152.7 \pm 4.61 \mu \mathrm{g} / \mathrm{mL})$. However, orlistat indicated $\mathrm{IC}_{50}$ value of $56.8 \pm 0.11 \mu \mathrm{g} / \mathrm{mL}$.

\subsection{Glucose Utilization in C3A Hepatocytes}

Glucose utilization and corresponding cytotoxicity in C3A hepatocytes are presented in Figure 7. All the samples showed weak glucose utilization in C3A hepatocytes compared with metformin treated cells which showed the highest glucose uptake. At $50 \mu \mathrm{g} / \mathrm{mL}$, only the blanched extract showed a very sharp drop in glucose uptake. Whereas, at the highest concentration tested $(100 \mu \mathrm{g} / \mathrm{mL})$, very weak or no glucose utilization was observed for all the three extracts. The results have also shown that higher concentrations of the extracts drastically reduced the viability of the cells, with the greatest reduction observed in the blanched extract. 


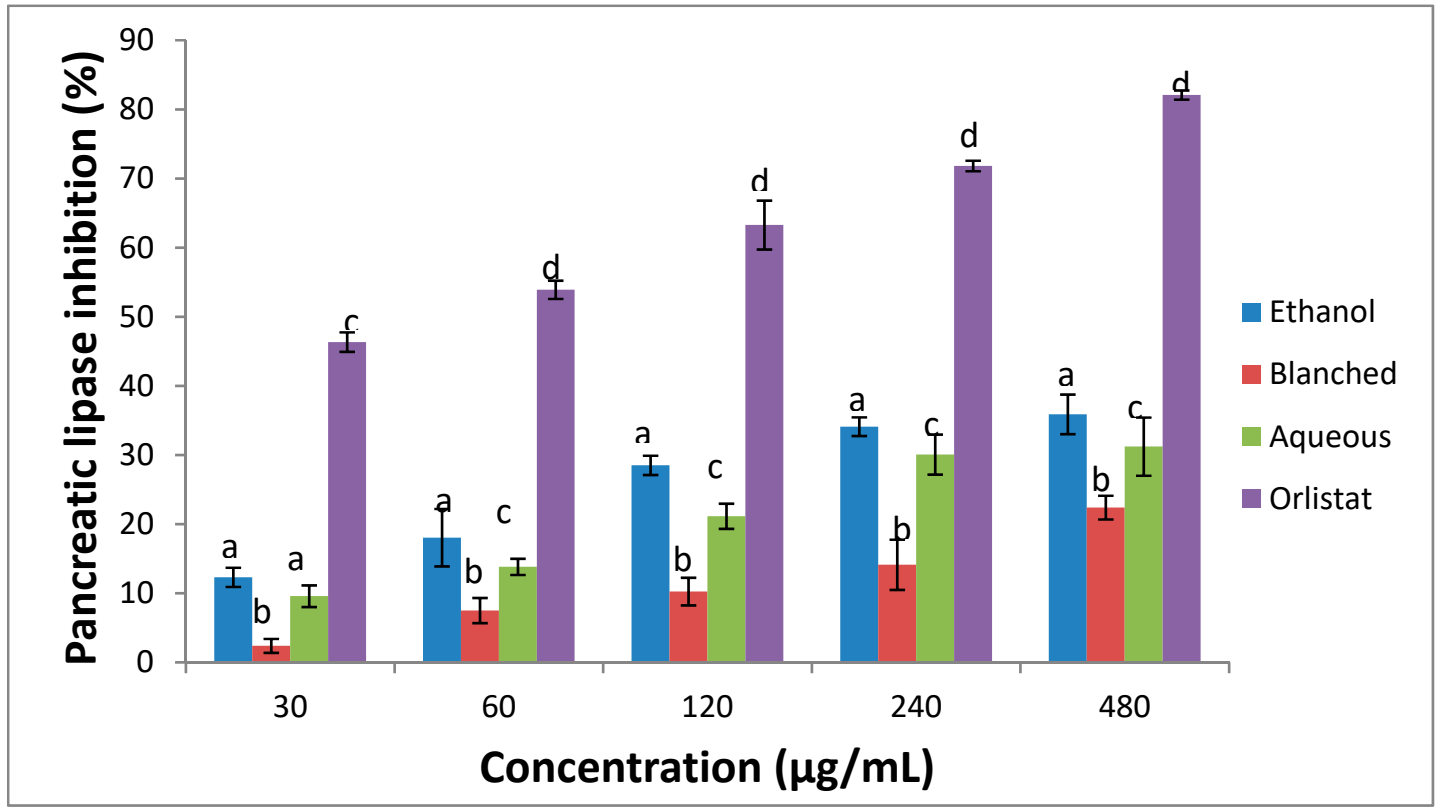

Figure 6. Pancreatic lipase inhibitory activity of $H$. arborescens leaf extracts and positive control (orlistat). Values are expressed as mean $\pm \mathrm{SD}(n=3)$. Mean separation by SD $(p<0.05)$. Set of bars (the same concentration) with different alphabets are different.
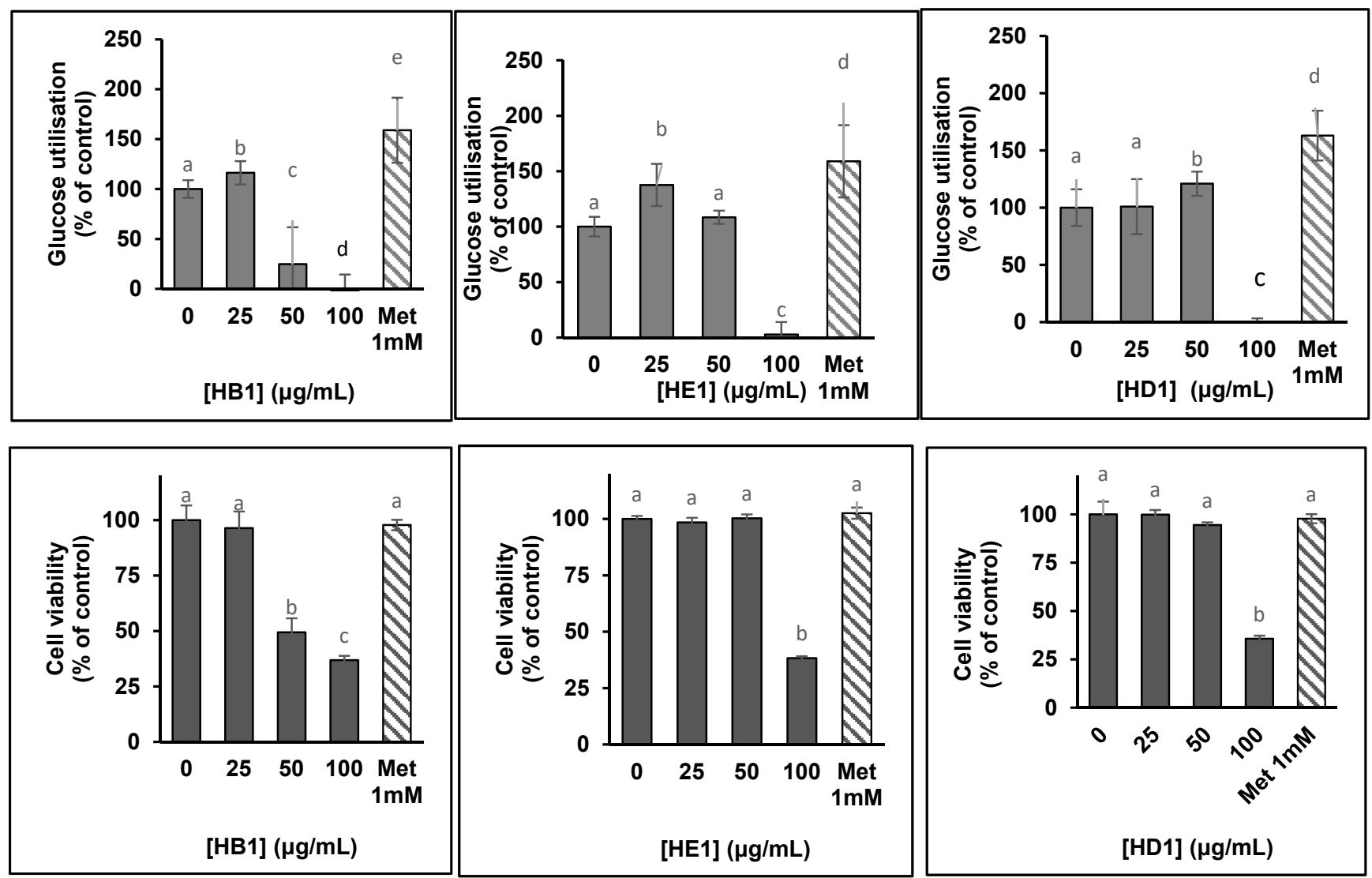

Figure 7. Effects of $H$. arborescens leaf extracts on glucose utilization in C3A cells and their corresponding effects on the C3A cell viability (MTT cytotoxicity) compared to the untreated cells. (Data are expressed as $\%$ of control $\pm \mathrm{SD}, n=3$ ). HB-Blanched; HE-Ethanol and HD-Aqueous extracts; Met-Metformin. Mean separation by SD $(p<0.05)$. Set of bars with different alphabets are significantly different. 


\subsection{Lipid Accumulation}

Lipid accumulation effect of $H$. arborescens leaf extracts on C3A cells compared with the control is depicted in Figure 8. A great increase in the levels of neutral lipids and phospholipids was obvious for the blanched extract $(75.95 \%$ at $50 \mu \mathrm{g} / \mathrm{mL}$ and $45.45 \%$ at $100 \mu \mathrm{g} / \mathrm{mL}$ respectively). However, for the ethanol extract, a great increase in neutral lipid accumulation $(63.11 \%)$ was only observed at the highest concentration $(100 \mu \mathrm{g} / \mathrm{mL})$. On the other hand, a relatively weaker, but statistically significant $(p>0.05)$, increase in neutral lipids $(18.07 \%)$ and phospholipids $(22.02 \%)$ at $50 \mu \mathrm{g} / \mathrm{mL}$ was observed in the aqueous extract. The corresponding images of the C3A cells treated with leaf extracts are indicated in Figure 9.
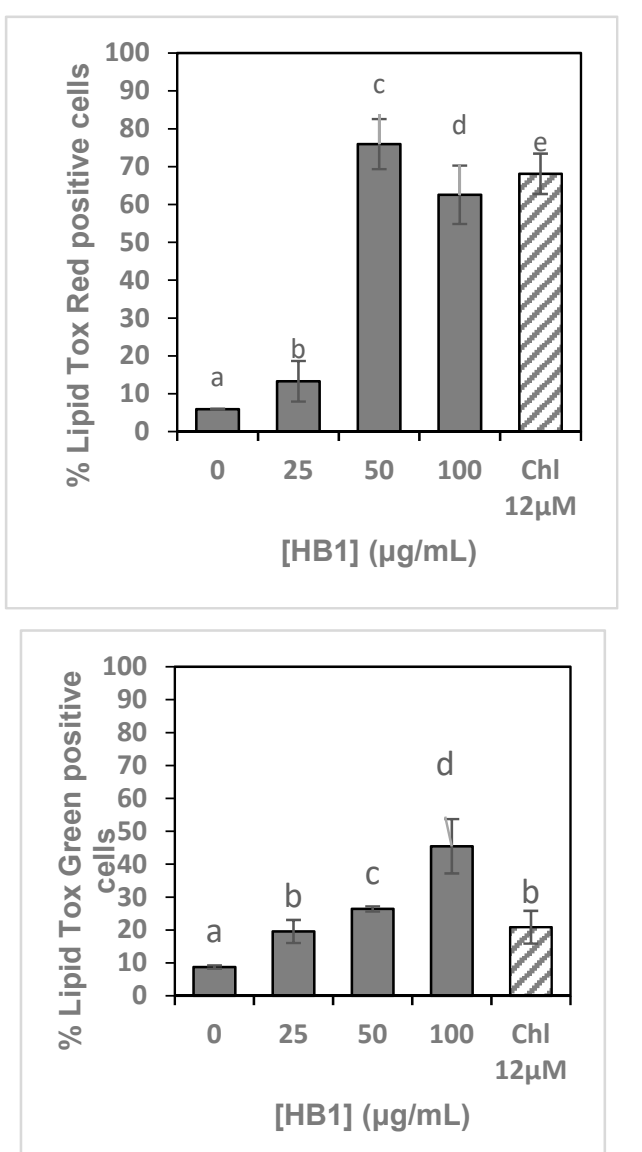
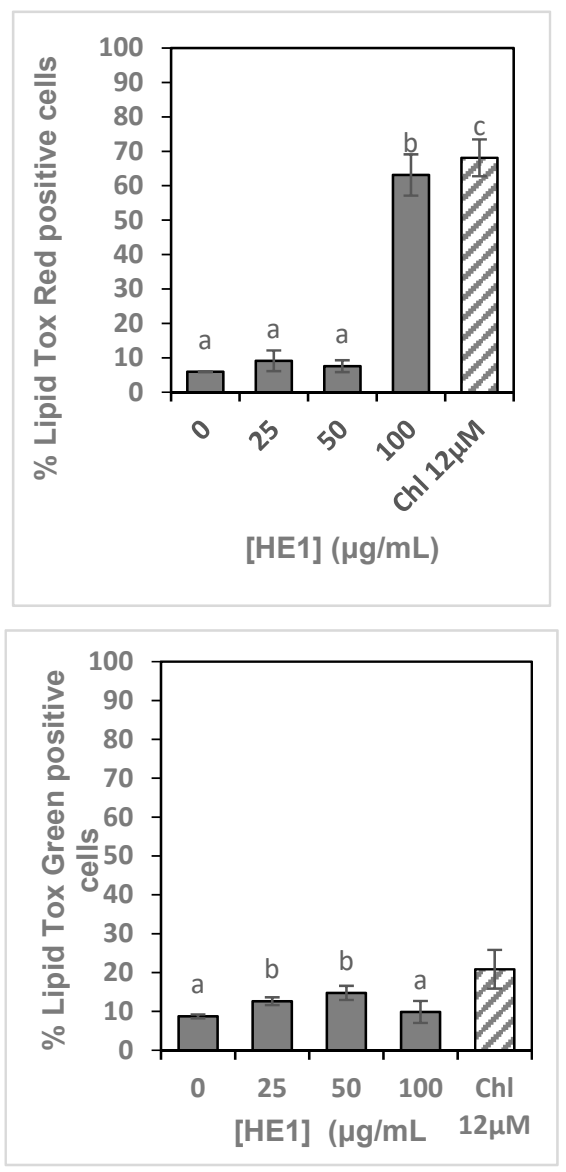
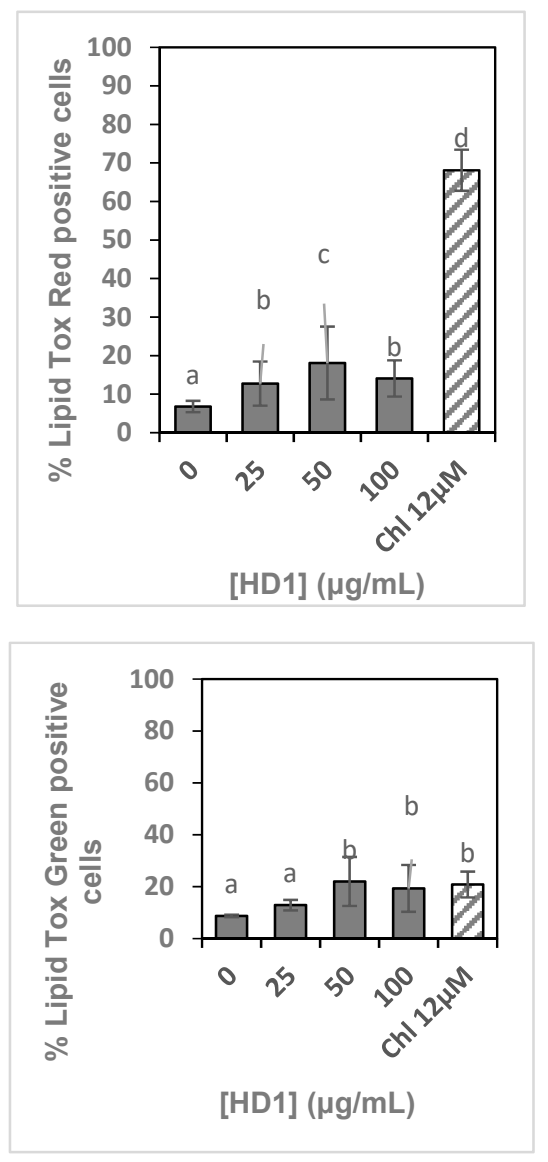

Figure 8. Neutral lipid (LipidTox Red) and phospholipid (LipidTox Green) accumulation in C3A cells treated with indicated extracts and chloroquine (positive control) for $48 \mathrm{~h}$. HB-Blanched; HE-Ethanol and HD—Aqueous extracts; Chl.-Chloroquine; Data is expressed as a percentage of cells staining positive for each treatment. Mean separation by SD $(p<0.05)$. Set of bars with different alphabets are significantly different. The corresponding images of the C3A cells treated with H. arborescence leaf extracts are indicated in Figure 9. 
A
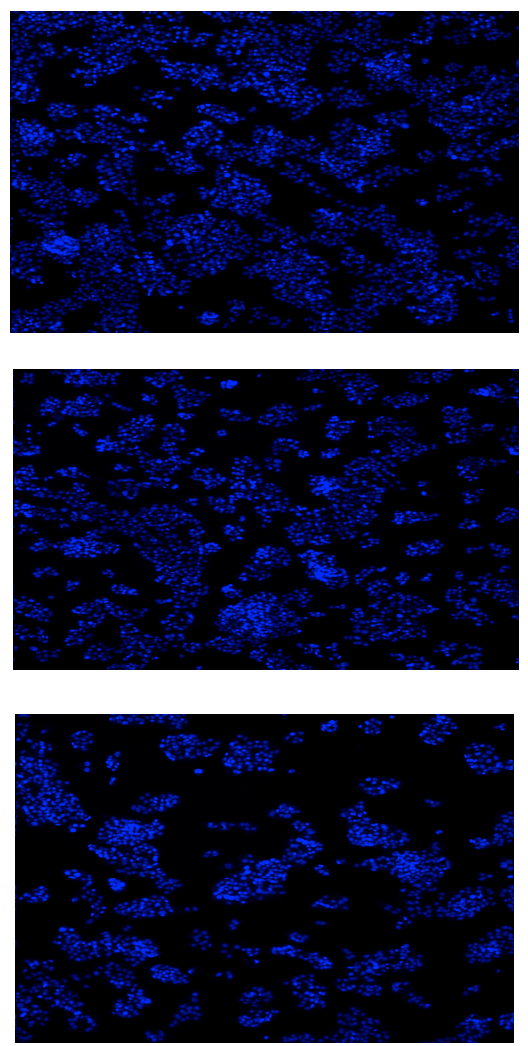

Blanched

Ethanol
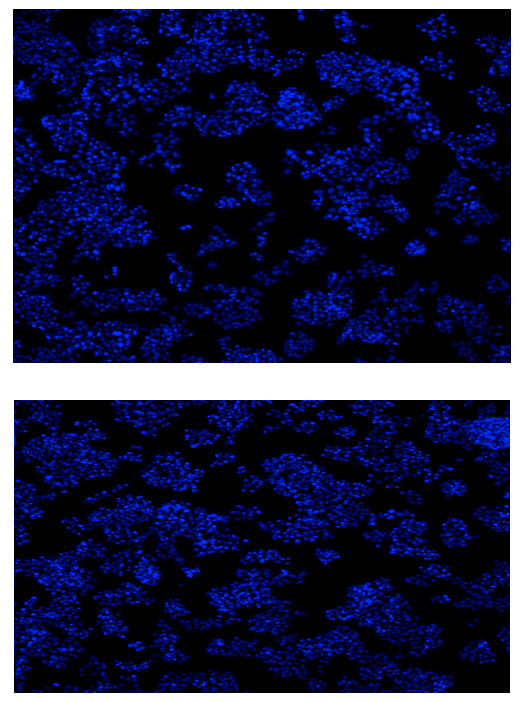

B
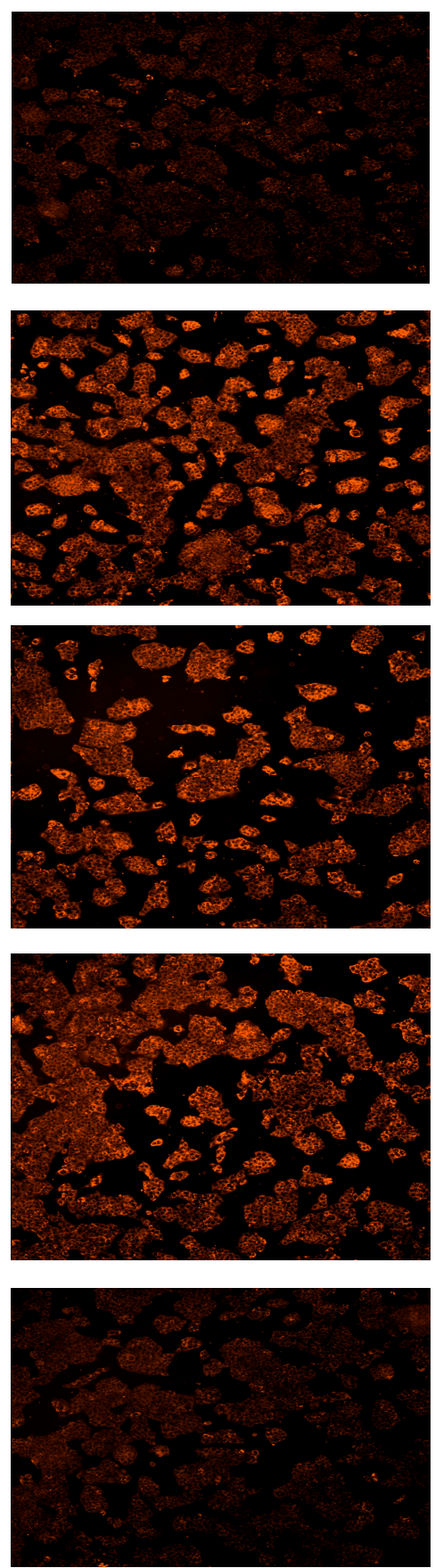

C
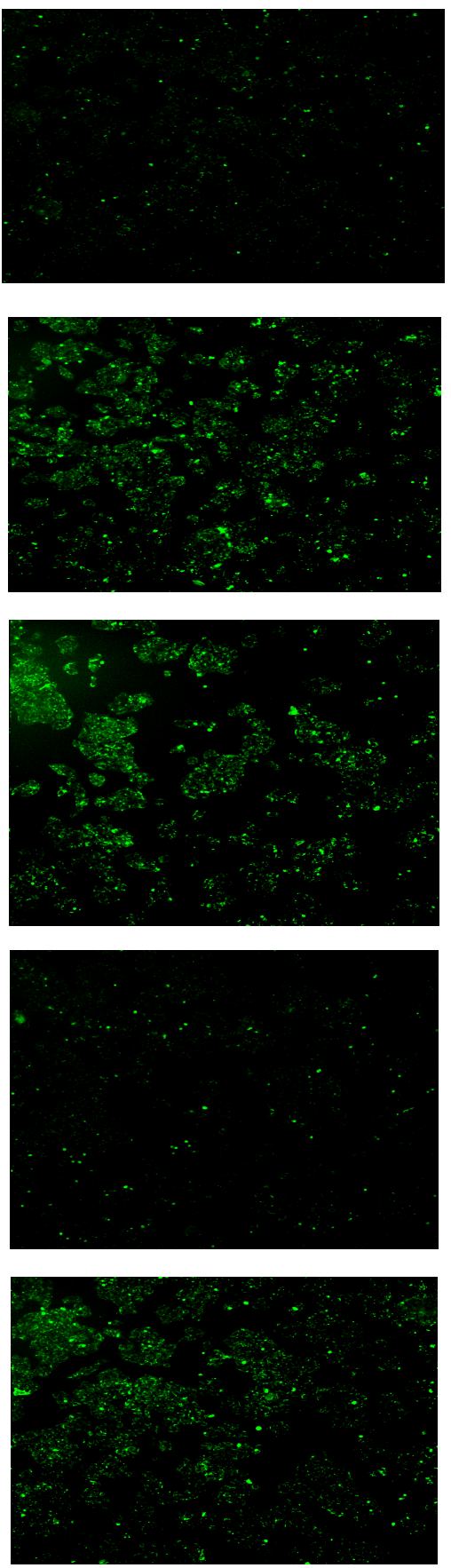

Figure 9. Images of C3A cells after $48 \mathrm{~h}$ treatment with $100 \mu \mathrm{g} / \mathrm{mL}$ each of ethanol, blanched and aqueous extracts of H. arborescens leaves obtained from Hoechst 33,342 staining. Column (A)—All nuclei, Column (B)_LipidTox Red (neutral lipids), Column (C)_LipidTox Green (phospholipids).

\subsection{Glucose Utilization in L6 Myocytes}

The effect of $H$. arborescens leaf extracts on glucose utilization in L6 myocytes, and its resultant cytotoxicity are revealed in Figure 10. Data was expressed as a percentage of the untreated control, and insulin was used as the positive control. While the insulin treated cells showed significantly higher glucose utilization than the extracts, a slight increase was observed only at 50 and $100 \mu \mathrm{g} / \mathrm{mL}$ for aqueous and ethanol extracts, with no significant increase for the blanched extract. However, for the aqueous extract there was a decline in glucose utilization from $154.89 \%$ at $50 \mu \mathrm{g} / \mathrm{mL}$ to $124.39 \%$ at $100 \mu \mathrm{g} / \mathrm{mL}$; while for the 
ethanol extract treated cells, glucose utilization only increased from $95.11 \%$ at $25 \mu \mathrm{g} / \mathrm{mL}$ to $107.82 \%$ at $50 \mu \mathrm{g} / \mathrm{mL}$ with no further increase at $100 \mu \mathrm{g} / \mathrm{mL}$. Furthermore, the cytotoxicity of the extracts on L6 cells measured and expressed in comparison with the control, showed significant levels of toxicity at high concentrations.
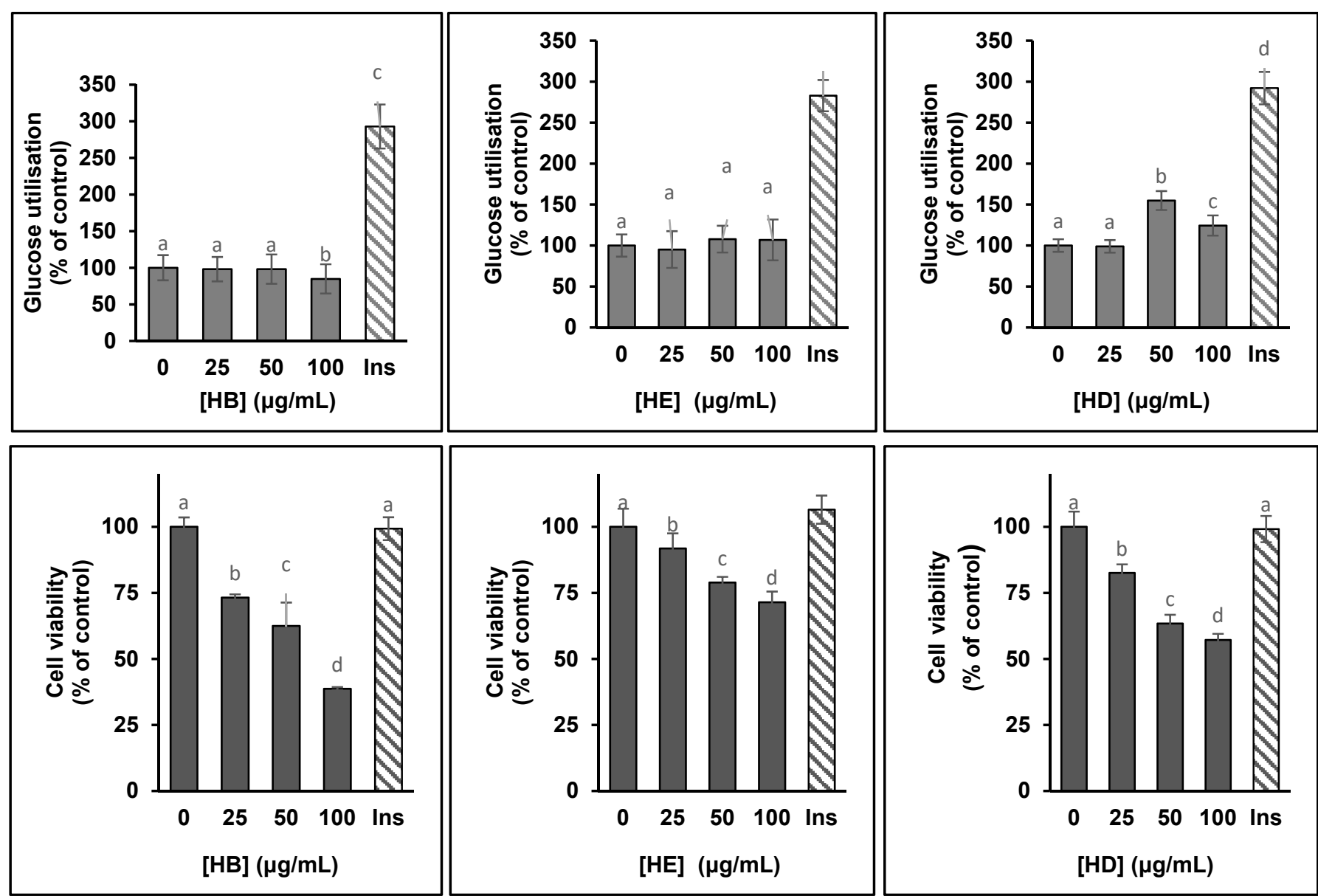

Figure 10. Effects of $H$. arborescens leaf extracts on glucose utilization in L6 cells and their corresponding effects on the L6 cell viability (MTT cytotoxicity) compared to the untreated cells. (Data are expressed as \% of control $\pm \mathrm{SD}, n=3$ ). HB-Blanched; HE-Ethanol and HD—Aqueous extracts; Met-Metformin. Mean separation by SD $(p<0.05)$. Set of bars with different alphabets are significantly different.

\section{Discussion}

The upsurge in cases of diabetes mellitus has become a global health challenge. Herbal medicines have been employed in the management of diabetes because they have reduced negative consequences when compared with the oral hypoglycemic agents such as sulfonylurea, metformin and troglitazone [2,32]. However, the use of these herbal remedies without proper scientific validation of their safety and acclaimed activity can be detrimental and sometimes deadly [33].

H. arborescens is a common medicinal plant traditionally used in South Africa for the management of diabetes mellitus $[18,19]$. Cytotoxic evaluation using cell lines is a common method for the screening of pharmaceutical products and synthetic organic compounds for their potential in the treatment of diseases [34]. The dose dependent but weak decline in cell density observed for both aqueous and ethanol extracts suggests that the risk for toxicity is minimal at physiologically relevant dosages as opposed to the blanched extract with more prominent decrease in cell density even at lower concentration. In addition, the sharp drop in cell density for all the extracts at higher concentrations may be due to the loss of propidium iodide positive cells during the staining procedure or due to a loss in 
proliferation and hence the absence of meaningful PI staining at lower concentrations. The cytotoxicity of the extracts also further explains the reason for the low glucose utilization observed for the extracts.

A-glucosidase and $\alpha$-amylase are key enzymes for intestinal carbohydrate digestion and the inhibition of these enzymes have been recognized as one of the therapeutic approaches for the regulation of postprandial hyperglycemia; an initial metabolic defect that occurs in the onset of diabetes mellitus [35-38]. Our previous studies by GC-MS analysis have documented the presence of $\alpha$-pinene, $\beta$-pinene, $\beta$-ocimene and D-limonene in $H$. arborescens leaves [39] and these components have been established to show some hypoglycemic activities [40,41]. Phenolic compounds such as phenols, terpenoids and flavonoids are possible natural sources of $\alpha$-glucosidase inhibitors which have been reported to repress glucose release from the liver as well as enhance hepatic glucose uptake [30,42]. Our previous work has established the phenolic constituents of $H$. arborescens leaves [43] and based on previous reports, the $\alpha$-glucosidase inhibitory activity of the three extracts observed in the present study could be attributed to the presence of polyphenolic compounds [44,45]. The high inhibition of $\alpha$-amylase enzyme by acarbose is linked to several unpleasant side effects such as abdominal disturbances, flatulence and diarrhea [46]. Therefore, the weak $\alpha$-amylase activity with corresponding stronger inhibition against $\alpha$-glucosidase observed for the $H$. arborescens leaf extracts is advantageous [47-49] and agrees with previous reports which proposed that phytochemicals are stronger inhibitors of $\alpha$-glucosidase compared to $\alpha$-amylase [44,50]. Moderate $\alpha$-glucosidase inhibitory potential obtained in the present study is comparable with previous results on hexane, ethyl acetate and methanol extracts of $H$. arborescens leaf and bark [51] as well as in some other members of the Apiaceae family such as C. Asiatica [52], A. graveolens [53], P. Anisum [48,54,55] and C. cyminum [56,57].

One mechanism through which phenolic compounds control glucose metabolism is to stimulate the muscle and fat cells to enhance their glucose utilization activities [58]. However, this study did not indicate a direct relationship between phenolic compounds and glucose utilization in L6 cells, as this was relatively weak for all the extracts especially the blanched extract, even though the extracts showed high phenolic compounds, with ethanol having the highest phenolic compounds. Arguably, the slight increase observed for ethanol extract at a concentration of $50 \mu \mathrm{g} / \mathrm{mL}$ might be attributed to the presence of higher hypoglycemic phenolic compounds [59] compared to the aqueous and blanched extract. Similarly, in C3A cells, glucose utilization declined at higher concentrations especially for the blanched extract and this could be because it proved to be the most toxic among the extracts assessed.

Excessive weight gain is a major risk factor for diabetes mellitus and lipid accumulation is used as a tool to check the level of adipogenesis in 3T3-L1 cells [60]. A reduction in lipid accumulation and inhibition of pancreatic lipase; an enzyme responsible for digestion of dietary fat, delaying fat deposition into adipose tissue, play a crucial role in reducing weight gain and obesity [61]. In this study, although lipase inhibition was quite low compared with orlistat (positive control), the lipase inhibitory activity obtained suggests that $H$. arborescens leaves may be a promising tool in managing excess weight and obesity. On the other hand, the results obtained for lipid accumulation in C3A cells with the use of Hoechst 33342/PI staining has shown that the three extracts do not significantly reduce lipid accumulation in C3A cells. These results suggest that the mechanism of action of $H$. arborescens leaves extracts may not be through reducing lipid accumulation.

\section{Conclusions}

This study presented new findings and established the pharmacological potential of $H$. arborescens leaves in controlling of diabetes and obesity. The cytotoxic activities as well as glucose utilization in L6 cell lines were evaluated. The results suggest a reasonable toxicity profile for the aqueous and ethanol extracts with limited risk for hepatotoxicity at physiologically relevant concentrations. Although relatively weak glucose utilization was obtained for the plant extracts, when compared to metformin, significant inhibition against 
$\alpha$-amylase and $\alpha$-glucosidase enzymes was observed for the ethanol and aqueous extracts. Our results have shown that both extracts may possibly exert their anti-diabetic properties by stimulating the inhibition of the carbohydrate digestive enzymes may therefore be promising for the management of diabetes mellitus. In addition, the extracts indicated considerable lipase inhibitory potential but no reasonable reduction in lipid accumulation in C3A cell lines.

Presumably, there is little or no study to justify the traditional use of H. arborescens leaves in the management of diabetes and obesity. Very importantly, precautions should be taken in the use of $H$. arborescens leaves at high concentrations to ensure safety and efficacy.

Author Contributions: T.O.A. and G.A.O. designed the experiments, performed the experiments, analyzed data, and wrote the draft. G.A.O. and A.J.A. supervised the study, coordinated, and revised the manuscript. All authors have read and agreed to the published version of the manuscript.

Funding: This research was funded by the Govan Mbeki Research Development Centre (GMRDC), University of Fort Hare, South Africa (grant number C127) and supported by the South Africa National Research Foundation: Research and Innovation Support and Advancement (NRF: RISA) CSURG: Grant No: 121264.

Institutional Review Board Statement: The study was conducted according to the guidelines of the Declaration of Helsinki, and approved by the Ethics Committee, University of Fort Hare Animal and Plant Use Research Ethics Committee, South Africa with protocol number OTA011SABI01/19/E.

Data Availability Statement: The data that support the findings of this study are available in this article.

Acknowledgments: Govan Mbeki Research Development Centre (GMRDC), University of Fort Hare, South Africa and National Research Foundation: Research and Innovation Support and Advancement (NRF: RISA) CSURG.

Conflicts of Interest: The authors declared no conflict of interest with respect to the research, authorship, and/or publication of this article.

\section{References}

1. Qaisar, M.N.; Chaudhary, B.A.; Sajid, M.U.; Hussain, N. Evaluation of $\alpha$-glucosidase inhibitory activity of dichloromethane and methanol extracts of Croton bonplandianum Baill. Trop. J. Pharm. Res. 2014, 10, 1833-1836. [CrossRef]

2. Unuofin, J.O.; Lebelo, S.L. Antioxidant effects and mechanisms of medicinal plants and their bioactive compounds for the prevention and treatment of Type 2 Diabetes: An Updated Review. Oxid. Med. Cell. Longev. 2020, 2020, 36. [CrossRef] [PubMed]

3. Keerthana, G.; Kalaivani, M.K.; Sumathy, A. In-vitro alpha amylase inhibitory and antioxidant activities of ethanolic leaf extract of Croton bonplandianum. Asian J. Pharm. Clin. Res. 2013, 6, 32-36.

4. Chawla, A.; Chawla, R.; Jaggi, S. Microvasular and macrovascular complications in diabetes mellitus: Distinct or continuum? Indian J. Endocrinol. Metab. 2016, 20, 546. [CrossRef] [PubMed]

5. Franco, O.L.; Rigden, D.J.; Melo, F.R.; Grossi-de-sa, M.F. Plant $\alpha$-amylase inhibitors and their interaction with insect $\alpha$-amylases structure, function, and potential for crop protection. Eur. J. Biochem. 2002, 269, 397-412. [CrossRef]

6. Notkins, A.L. Immunologic and genetic factors in Type1 Ficus deltoidea diabetes. J. Biol. Chem. 2002, 277, 43545-43548. [CrossRef]

7. Zheng, C.D.; Duan, Y.Q.; Gao, J.M.; Ruan, Z.G. Screening for anti-lipase properties of 37 traditional Chinese medicinal herbs. J. Chin. Med. Assoc. 2010, 1, 319-324. [CrossRef]

8. Sangeetha, R.; Vedasree, N. In vitro $\alpha$-amylase Inhibitory activity of the leaves of Thespesia populnea. ISRN Pharmacol. 2012, 2012, 1-4. [CrossRef]

9. Balan, K.; Ratha, P.; Prakash, G.; Viswanathamurthi, P.; Adisakwattana, S.; Palvannan, T. Evaluation of in vitro $\alpha$-amylase and $\alpha$-glucosidase inhibitory potential of $\mathrm{N}_{2} \mathrm{O}_{2}$ Schiff base Zn complex. Arab. J. Chem. 2017, 10, 732-738. [CrossRef]

10. Barnes, A.S. The epidemic of obesity and diabetes: Trends and treatments. Tex. Heart Inst. J. 2011, 38, 142.

11. Seyedan, A.; Alshawsh, M.A.; Alshagga, M.A.; Koosha, S.; Mohamed, Z. Medicinal plants, and their inhibitory activities against pancreatic lipase: A review. Evid. Based Complement. Alternat. Med. 2015, 10, 2015. [CrossRef]

12. Pontarolo, R.; Sanches, A.C.C.; Wiens, A.; Perlin, C.M.; Tonin, F.S.; Borba, H.H.L.; Lenzi, L.; da Silva Penteado, S.T. Pharmacological Treatments for Type 2 Diabetes. Treat. Type 2 Diabetes. 2015, 147-184. [CrossRef]

13. Eddouks, M.; Chattopadhyay, D.; De Feo, V.; Cho, W.C.S. Medicinal plants in the prevention and treatment of chronic diseases 2013. Evid. Based Complement. Alternat. Med. 2014, 2014, 180981. [CrossRef] [PubMed]

14. Jamila, F.; Mostafa, E. Ethnobotanical survey of medicinal plants used by people in Oriental Morocco to manage various ailments. J. Ethnopharmacol. 2014, 154, 76-87. [CrossRef] 
15. Patel, D.K.; Kumar, R.; Laloo, D.; Hemalatha, S. Diabetes mellitus: An overview on its pharmacological aspects and reported medicinal plants having antidiabetic activity. Asian Pac. J. Trop. Biomed. 2012, 2, 411-420. [CrossRef]

16. Khan, M.F.; Rawat, A.K.; Khatoon, S.; Hussain, M.K.; Mishra, A.; Negi, D.S. In vitro and in vivo antidiabetic effect of extracts of Melia azedarach, Zanthoxylum alatum, and Tanacetum nubigenum. Integr. Med. Res. 2018, 7, 176-183. [CrossRef] [PubMed]

17. Chipiti, T.; Ibrahim, M.A.; Singh, M.; Islam, M.S. In vitro $\alpha$-amylase and $\alpha$-glucosidase inhibitory effects and cytotoxic activity of Albizia antunesiana extracts. Pharmacogn. Mag. 2015, 11, 231.

18. Erasto, P.; Adebola, P.; Grierson, D.; Afolayan, A.J. An ethnobotanical study of plants used for the treatment of diabetes in the Eastern Cape Province, South Africa. Afr. J. Biotechnol. 2005, 4, 1458-1460.

19. Afolayan, A.J.; Sunmonu, T.O. In vivo Studies on Antidiabetic Plants used in South African Herbal Medicine. J. Clin. Biochem Nutr. 2010, 47, 98-106. [CrossRef]

20. Odeyemi, S.; Bradley, G. Medicinal plants used for the traditional management of diabetes in the Eastern Cape, South Africa: Pharmacology and toxicology. Molecules 2018, 23, 2759. [CrossRef]

21. Maroyi, A. Heteromorpha arborescens: A review of its botany, medicinal uses, and pharmacological properties. Asian J. Pharm. Clin. Res. 2018, 11, 75-82. [CrossRef]

22. Schmidt, E.; Lotter, M.; McCleland, W. Trees and Shrubs of Mpumalanga and Kruger National Park; Jacana Media: Pretoria, South Africa, 2002.

23. Van Wyk, B.E.; Gericke, N. People's Plants: A Guide to Useful Plants of Southern Africa; Briza Publications: Pretoria, South Africa, 2007.

24. Stangeland, T.; Alele, P.E.; Katuura, E.; Lye, K.A. Plants used to treat malaria in Nyakayojo sub-county, Western Uganda. J. Ethnopharmacol. 2011, 137, 154-166. [CrossRef]

25. Van Wyk, B.E.; Van Oudtshoorn, B.; Gericke, N. Medicinal Plants of South Africa; Briza Publications: Pretoria, South Africa, 2013.

26. Nkomo, M.; Nkeh-Chungag, B.N.; Kambizi, L.; Ndebia, E.J.; Sewani-Rusike, C.; Iputo, J.E. Investigation of the antinociceptive and anti-inflammatory properties of Heteromorpha arborescens (Apiaceae). Afr. J. Tradit. Complement. Altern. Med. 2011, 8, 412-419. [CrossRef] [PubMed]

27. Nkomo, M.; Kambizi, L. Antimicrobial activity of Gunnera perpensa and Heteromorpha arborescens var. abyssinica. J. Med. Plant. Res. 2009, 3, 1051-1055.

28. Odeyemi, S.; Dewar, J. In vitro Antidiabetic activity affecting glucose uptake in HepG2 cells following their exposure to extracts of Lauridia tetragona (Lf) RH Archer. Processes 2020, 8, 33. [CrossRef]

29. Bustanji, Y.; Issa, A.; Mohammad, M.; Hudaib, M.; Tawah, K.; Alkhatib, H.; Almasri, I.; Al-Khalid, B. Inhibition of hormone sensitive lipase and pancreatic lipase by Rosmarinus officinalis extract and selected phenolic constituents. J. Med. Plant. Res. 2010, $4,2235-2242$.

30. Sagbo, I.J.; van de Venter, M.; Koekemoer, T.; Bradley, G. In vitro antidiabetic activity and mechanism of action of Brachylaena elliptica (Thunb.) DC. Evid. Based Complementary Altern. Med. 2018, 2018, 4170372. [CrossRef]

31. Van de Venter, M.; Roux, S.; Bungu, L.C.; Louw, J.; Crouch, N.R.; Grace, O.M.; Maharaj, V.; Pillay, P.; Sewnarian, P.; Bhagwandin, N. Antidiabetic screening and scoring of 11 plants traditionally. J. Ethnopharmacol. 2008, 119, 81-86. [CrossRef] [PubMed]

32. Fowler, M.J. Diabetes treatment, part 2: Oral agents for glycemic management. Clin. Diabetes. 2007, 25, 131-134. [CrossRef]

33. Unuofin, J.O.; Otunola, G.A.; Afolayan, A.J. In vitro $\alpha$-amylase, $\alpha$-glucosidase, lipase inhibitory and cytotoxic activities of tuber extracts of Kedrostis africana (L.) Cogn. Heliyon. 2018, 4, 810. [CrossRef]

34. Abifarin, T.O.; Otunola, G.A.; Afolayan, A.J. Cytotoxicity evaluation and anti-inflammatory potentials of Cucumis africanus L.f. leaves. Med. Plants Int. J. Phytomed. Relat. Ind. 2020, 12, 48-52. [CrossRef]

35. Kim, Y.M.; Jeong, Y.K.; Wang, M.H.; Lee, W.Y.; Rhee, H.I. Inhibitory effect of pine extract on $\alpha$-glucosidase activity and postprandial hyperglycemia. Nutrition 2005, 21, 756-761. [CrossRef]

36. Bhandari, M.R.; Anurakkun, N.J.; Hong, G.; Kawabata, J. $\alpha$-glucosidase and $\alpha$-amylase inhibitory activities of Nepalese medicinal herb Pakhanbhed (Bergeniaciliata, Haw.). Food Chem. 2008, 106, 247-252. [CrossRef]

37. Deshpande, M.C.; Venkateswarlu, V.; Babu, R.K.; Trivedi, R.K. Design and evaluation of oral bio adhesive controlled release formulations of miglitol, intended for prolonged inhibition of intestinal $\alpha$-glucosidases and enhancement of plasma glucagon like peptide-1 levels. Int. J. Pharm. 2009, 380, 16-24. [CrossRef]

38. Mohammed, E.A.H.; Siddiqui, M.J.A.; Ang, L.F.; Sadikun, A.; Chan, S.H.; Tan, S.C. Potent $\alpha$-glucosidase, and $\alpha$-amylase inhibitory activities of standardized 50\% ethanolic extracts and sinensetin from Orthosiphon stamineus Benth as anti-diabetic mechanism BMC Complement. Altern Med. 2012, 12, 176. [CrossRef] [PubMed]

39. Abifarin, T.O.; Otunola, G.A.; Afolayan, A.J. Chemical Composition of Essential Oils Obtained from Heteromorpha arborescens (Spreng.) Cham. and Schltdl Leaves Using Two Extraction Methods. Sci. World J. 2020, 2020, 1-6. [CrossRef] [PubMed]

40. Sebai, H.; Selmi, S.; Rtibi, K.; Souli, A.; Gharbi, N.; Sakly, M. Lavender (Lavandula stoechas L.) essential oils attenuate hyperglycemia and protect against oxidative stress in alloxan-induced diabetic rats. Lipids Health Dis. 2013, 12, 1-9. [CrossRef] [PubMed]

41. Ibrahim, F.A.; Usman, L.A.; Akolade, J.O.; Idowu, O.A.; Abdulazeez, A.T.; Amuzat, A.O. Antidiabetic potentials of Citrus aurantifolia leaf essential oil. Drug Res. 2019, 69, 201-206. [CrossRef] [PubMed]

42. Maria, J.K.M.; Rajesh, J.; Mandal, A.K.A.; Sampath, N. Antioxidant and antimicrobial activity of individual catechin molecules: A comparative study between gallated and epimerized catechin molecules. Eur. J. Exp. Biol. 2011, 3, 145-153. 
43. Abifarin, T.O.; Otunola, G.A.; Afolayan, A.J. Assessment of the phytochemical, antioxidant, and antibacterial activities of Heteromorpha arborescens (Spreng.) Cham \& Schltdl. leaf extracts. F1000Research 2020, 9, 1079. [PubMed]

44. Abdallah, H.M.; Salama, M.M.; Abd-elrahman, E.H.; El-Maraghy, S.A. Antidiabetic activity of phenolic compounds from pecan bark in streptozotocin-induced diabetic rats. Phytochem. Lett. 2011, 4, 337-341. [CrossRef]

45. Piluzza, G.; Bullitta, S. Correlations between phenolic content and antioxidant properties in twenty-four plant species of traditional Ethno veterinary use in the Mediterranean area. Pharm Biol. 2011, 49, 240-247. [CrossRef]

46. Mwakalukwa, R.; Amen, Y.; Nagata, M.; Shimizu, K. Postprandial Hyperglycemia Lowering Effect of the Isolated Compounds from Olive Mill Wastes-An Inhibitory Activity and Kinetics Studies on $\alpha$-Glucosidase and $\alpha$-Amylase Enzymes. ACS Omega 2020, 5, 20070-20079. [CrossRef]

47. Cho, M.; Han, J.H.; You, S. Inhibitory effects of fucan sulfates on enzymatic hydrolysis of starch. LWT Food Sci. Technol. 2011, 44, 1164-1171. [CrossRef]

48. Ohikhena, F.U.; Wintola, O.A.; Afolayan, A.J. Investigating the antidiabetic potential of Phragmanthera capitata, mistletoe harvested from rubber tree. J Herbs Spices Med. Plants. 2017, 24, 151-159. [CrossRef]

49. Unuofin, J.O.; Otunola, G.A.; Afolayan, A.J. Inhibition of key enzymes linked to obesity and cytotoxic activities of whole plant extracts of Vernonia mesplilfolia Less. Processes 2019, 7, 841. [CrossRef]

50. Kwon, Y.I.; Apostolidis, E.; Kim, Y.C.; Shetty, K. Health benefits of traditional corn, beans, and pumpkin: In vitro studies for hyperglycemia and hypertension management. J. Med. Food 2007, 1, 266-275. [CrossRef] [PubMed]

51. Sunil, C.; Kumar, V.; Van Staden, J. In vitro $\alpha$-glucosidase inhibitory, total phenolic composition, antiradical, and antioxidant potential of Heteromorpha arborescens (Spreng.) Cham. \& Schltdl. leaf and bark extracts. S. Afr. J. Bot. 2019, 124, 380-386.

52. Gayathri, V.; Lekshmi, P.; Padmanabhan, R.N. Anti-diabetes activity of ethanol extract of Centella asiatica (L.) Urban (whole plant) in Streptozotocin-induced diabetic rats, isolation of an active fraction and toxicity evaluation of the extract. Int. J. Med. Aromat. Plants. 2011, 3, 278-286.

53. Yaser, A.J.; Muneer, A.; Abdelhafid, B.; Dauodi, C.S.; Hammadi, L. Chemical and phytochemical analysis of some antidiabetic plants in Yemen. Int J. Res. Pharm. 2013, 4, 72-76. [CrossRef]

54. Shobha, R.I.; Rajeshwari, C.U.; Andallu, B. Anti-peroxidative and antidiabetic activities of aniseeds (Pimpinella anisum L.) and identification of bioactive compounds. Am. J. Phytomed. Clin. Ther. 2013, 5, 516-527.

55. Farzaneh, V.; Gominho, J.; Pereira, H.; Carvalho, I.S. Screening of the antioxidant and enzyme inhibition potentials of Portuguese Pimpinella anisum L. seeds by GC-MS. Food Anal. Methods 2018, 11, 2645-2656. [CrossRef]

56. Lee, H.S. Cuminaldehyde: Aldose Reductase and $\alpha$-glucosidase inhibitor derived from Cuminum cyminum L. seeds. J. Agric. Food Chem. 2005, 53, 2446-2453. [CrossRef] [PubMed]

57. Ardeshirlarijani, E.; Namazi, N.B.; Jalili, R.; Saeedi, M.; Imanparast, S.; Adhami, H.R.; Faramarzi, M.A.; Ayati, M.H.; Mahdavi, M.; Larijani, B. Potential Anti-obesity effects of some medicinal herb: In vitro $\alpha$-amylase, $\alpha$-glucosidase and lipase Inhibitory Activity. Int. J. Adv. Biol. Biomed. Res. 2019, 5, 2.

58. Olaokun, O.O.; Mkolo, N.M.; Mogale, M.A.; King, P.H. Phytochemical Screening, Antioxidant, Anti-inflammatory and Glucose Utilization Activities of Three South African Plants Used Traditionally to Treat Diseases. Biol Med. (Aligarh). 2017, 9, 2. [CrossRef]

59. Mukherjee, P.K.; Maiti, K.; Mukherjee, K.; Houghton, P.J. Leads from Indian medicinal plants with hypoglycemic potentials. J. Ethnopharmacol. 2006, 15, 1-28. [CrossRef]

60. Van Herpen, N.A.; Schrauwen-Hinderling, V.B. Lipid accumulation in non-adipose tissue and Lipotoxicity. Physiol. Behav. 2008, 23, 231-241. [CrossRef]

61. Dechakhamphu, A.; Wongchum, N. Screening for anti-pancreatic lipase properties of 28 traditional Thai medicinal herbs. Asian Pac. J. Trop. Biomed. 2015, 5, 1042-1045. [CrossRef] 